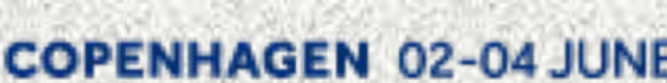

\section{Pilot Implantation of preloaded ephedrine syringes in a tertiary university hospital: Audit on satisfaction and cost-effectiveness}

\author{
Brogly N.1, Kollmann A. ${ }^{1}$, Alsina E. ${ }^{1}$, Moro M. ${ }^{2}$, Guasch E. ${ }^{1}$, Gilsanz F.1 \\ 1.Department of Anaesthesia and Reanimación, ${ }^{2}$.Department of Pharmacy. Hospital Universitario La Paz, Madrid - Spain
}

Background: The latest European guidelines about medication safety recommend the use of preloaded medication. This audit assessed users' satisfaction and cost effectiveness of the implantation of preloaded ephedrine syringes in a tertiary university hospital in Spain.

Material and methods: Ephedrine ampules were substituted with preloaded ephedrine syringes in the maternal area of the anesthesia department of our hospital (6 gynecological operating rooms (OR), 2 obstetric OR, 10 labor rooms and 13 intensive care beds).

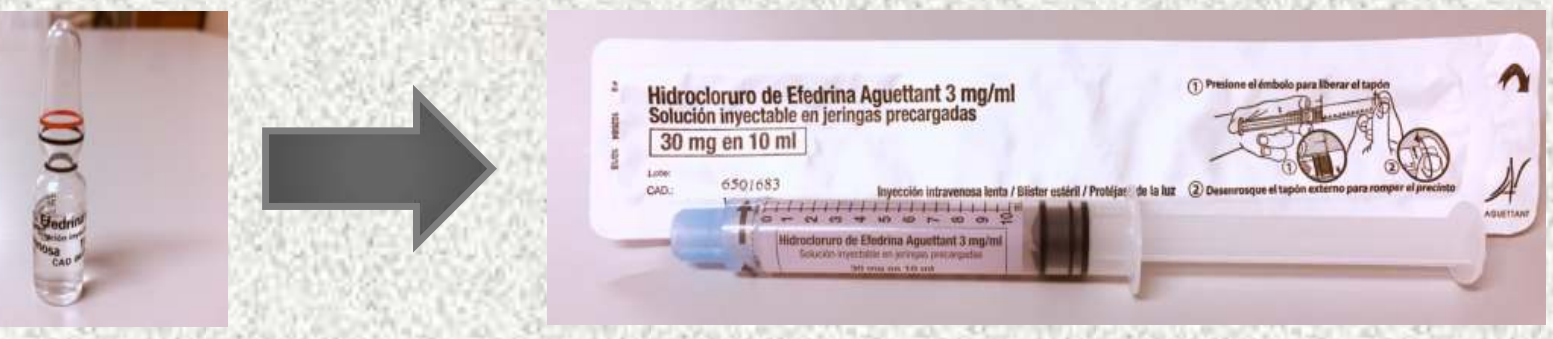

3 months after implementation we assessed:

- users' satisfaction

- cost-effectiveness of the change: expense for the purchase of the medication during the pilot period, compared with the same period the year before.

1. Es Ud.:

1. Es Ud.:
\begin{tabular}{|l|l|l|l|}
\hline Médico Anestesiólogo & Médico de otra especialidad & Enfermera & Auxiliar de enfermería \\
\hline
\end{tabular}

2. Su experiencia profesional:
\begin{tabular}{|l|l|l|l|}
\hline Residente/alumno & Titulado $<5$ años & Titulado [5-10]años & Titulado $>10$ años \\
\hline
\end{tabular}

3. En relación con la información sobre el cambio de ampollas de efedrina a jeringas precargadas, ¿calificaría la información recibida sobre el cambio?

\begin{tabular}{|c|c|c|c|c|c|}
\hline Muy mala & Mala & Indiferente & Buena & Muy buena & Inexistente \\
\hline
\end{tabular}

4. ¿Sabe dónde está guardada la efedrina en el quirófano/reanimación?

5. ¿Sabe dónde está guardada la efedrina en el almacén/carros de parada cardiaca?

6. De 0 a 10,0 siendo muy mala y 10 excelente cuál es su nivel de satisfacción de la efedrina precargada comparado con la ampolla anteriormente disponible en el quirófano?

\begin{tabular}{|l|l|l|l|l|l|l|l|l|l|l|}
\hline $\mathbf{0}$ & $\mathbf{1}$ & $\mathbf{2}$ & $\mathbf{3}$ & $\mathbf{4}$ & $\mathbf{5}$ & $\mathbf{6}$ & $\mathbf{7}$ & $\mathbf{8}$ & $\mathbf{9}$ & $\mathbf{1 0}$ \\
\hline
\end{tabular}

¿Considera Ud. que ha aportado algo el cambio?

Justificar:

8. Si se pudiera introducir más medicación precargada en la zona quirúrgica/de reanimación, ¿lo considerarí \begin{tabular}{|l|l|} 
beneficioso? & $\mathrm{Si}$ \\
\hline
\end{tabular} ¿Cuáles?:
Results: $35 / 35$ distributed questionnaires were collected. Mean satisfaction was $8.5 / 10$.

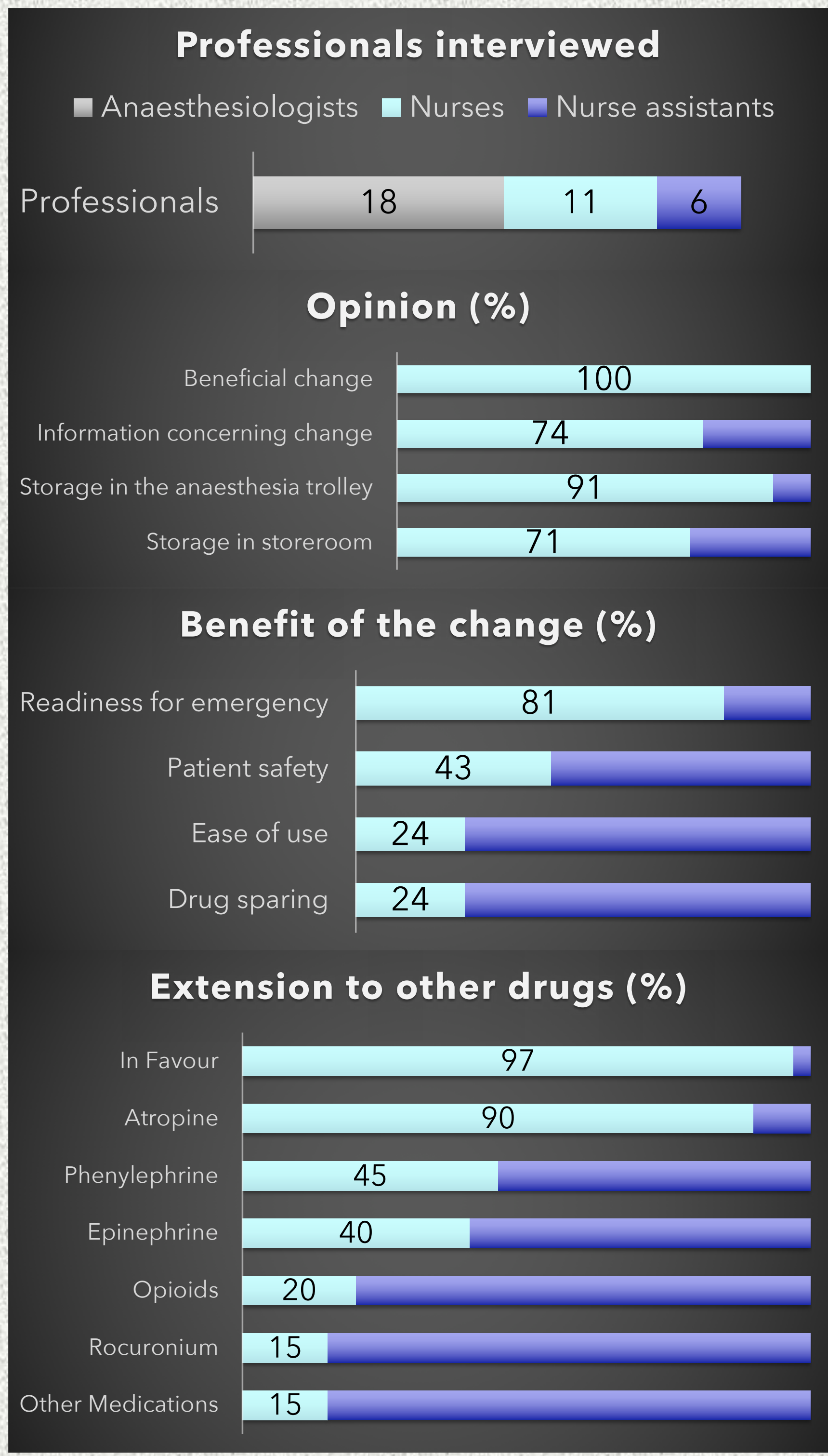

Total cost of the implementation (First supply incl): $<400 €$

Ephedrine consumption: $61 \% \downarrow$ compared to ampules

Long term costs after implementation: Difference $<20 € /$ week

Discussion and conclusion: The implantation of preloaded syringes of ephedrine was very well perceived by all professionals implicated in its use. They are in favor of an extension to other medications. The over cost of the implementation is compensated by the benefits to patient safety: decrease in medication and dilution errors and readiness to use in case of emergency. 